\title{
Kluyveromyces bacillisporus sp. nov., a Yeast from Emory Oak Exudate
}

\author{
MARC-ANDRÉ LACHANCE, ${ }^{1 *}$ HERMAN J. PHAFF,${ }^{2}$ AND WILLIAM T. STARMER ${ }^{3}$ \\ Department of Plant Sciences, University of Western Ontario, London, Ontario N6A 5B7, Canada ${ }^{1}$; \\ Department of Food Science and Technology, University of California, Davis, California 95616 ${ }^{2}$; and
} Department of Biology, Syracuse University, Syracuse, New York $13244^{3}$

\begin{abstract}
Three strains of a new diploid species of the genus Kluyveromyces van der Walt emend. van der Walt were isolated from exudates of Emory oak (Quercus emoryi) trees in Arizona. In physiological characteristics and nuclear DNA base composition (38 mol\% G+C) these isolates most closely resemble Kluyveromyces africanus and Kluyveromyces delphensis, but the three taxa are genetically unrelated, as shown by DNA reassociation and ribosomal DNA restriction mapping. The morphology of these organisms is typical of the genus Kluyveromyces, except that the mature ascospores (four and occasionally more spores per ascus) are characteristically bacilliform rather than spheroidal, ellipsoidal, or reniform. Mitochondrial DNA $(21 \mathrm{~mol} \% \mathrm{G}+\mathrm{C})$ is present in unusually large proportions (ca. one-half of the total DNA). The type strain of Kluyveromyces bacillisporus sp. nov. is strain UWO(PS) 85-349.2 (= ATCC $90019=$ CBS 7720).
\end{abstract}

Emory oak (Quercus emoryi Torr.) produces seasonal exudates which harbor an interesting yeast flora (2). Drosophila species visit these exudates, as well as those of nearby cottonwoods (Populus fremontii Wats.), with the result that these two trees exhibit some overlap in their yeast compositions. However, the yeast community of Emory oak is more typical of that of other oaks $(1,7,9)$ in that it contains species such as Pichia pastoris, Saccharomyces dairensis, Kluyveromyces lactis var. drosophilarum, or Candida norvegica, as well as other less specific yeasts, such as Saccharomyces cerevisiae. Some samples contain a previously unknown species of the genus Kluyveromyces, described in this paper as Kluyveromyces bacillisporus.

\section{MATERIALS AND METHODS}

Yeast isolation and identification. Yeasts were isolated by direct streak plating of exudate onto acidified ( $\mathrm{pH}$ 3.7) YM agar (Difco). Yeasts were identified by standard methods (12). Growth responses were studied by replica plating, and amino acid requirements were assessed by auxanography in amino acid-free yeast nitrogen base (Difco)-glucose agar. The strains are maintained in YM agar (Difco) and in $10 \%$ glycerol in liquid nitrogen.

Nucleic acid analyses. Nuclear and mitochondrial DNA base compositions were determined by the buoyant density method in CsCl. DNA from Micrococcus luteus ICPB 2039 (International Collection of Phytopathogenic Bacteria, Department of Bacteriology, University of California, Davis), with a buoyant density of $1.7309 \mathrm{~g} / \mathrm{ml}$, was used as a reference. DNA extraction, purification, and reassociation were carried out by the procedures of Price et al. (11), except that purified DNA was concentrated by electrophoresis in a concentrator (ISCO, Lincoln, Nebr.). During buoyant density equilibrium centrifugation to determine DNA base composition, it became evident that the DNA of $K$. bacillisporus contained an exceptionally large fraction of a second type of DNA, which had a low $\mathrm{G}+\mathrm{C}$ content (ca. $21 \mathrm{~mol} \%$ ); the amount of this DNA was approximately one-half the amount of nuclear DNA (estimated from absorbancy scans of ultra-

\footnotetext{
* Corresponding author.
}

centrifuged cells). We assumed that this fraction, which was not present in significant amounts in the other Kluyveromyces species, represents mitochondrial DNA.

Although rapidly renaturing sequences are routinely removed in labelled DNA by brief reassociation followed by fractionation on a hydroxyapatite column at $60^{\circ} \mathrm{C}$, the large amount of the low-G+C-content component present incited us to purify further the nuclear DNA used for the hybridization experiments by performing an additional step. This additional purification was accomplished by loading partially purified DNA in a $0.2 \mathrm{M} \mathrm{NaP}$ solution onto a hydroxyapatite column, washing the preparation with the same buffer, and eluting it with $0.24 \mathrm{M} \mathrm{NaP}$ buffer. This yielded nuclear DNA that was essentially free of the presumed mitochondrial component.

Two DNA hybridization experiments were performed. In experiment 1 (see Table 2) the DNA was labelled with ${ }^{32} \mathrm{P}$ by using the random primed labelling procedure, modified as described by Lachance et al. (8). Because of the relatively high values for zero-time binding and self-renaturation, reassociation was repeated with ${ }^{125}$ I-labelled DNA (experiment 2 ), as described by Holzschu et al. (3).

The extents of heteroduplex formation are reported below as the levels of relative binding to hydroxyapatite. For extraction and restriction mapping of ribosomal DNA the methods described by Lachance (6) were used.

Phenetic analysis. Phenotypic similarity patterns were analyzed by coding the standard descriptors given in Table 1 on ordinal scales, constructing a Euclidean distance matrix, and plotting the taxa as a function of the distances obtained with Fortran program NMDS (6a), which is based on the nonmetric multidimensional scaling algorithm of Kruskal (4). The restriction site data were coded as binary variables, and their relative mismatch matrix was calculated and analyzed by the NMDS program.

\section{RESULTS}

Strains UWO(PS) $85-349.2^{\mathrm{T}}$ ( $\mathrm{T}=$ type strain), UWO(PS) 85-353.1, and UWO(PS) 85-359.2 were isolated from exudates of three different oaks growing in the same vicinity near Tucson, Ariz. The morphological characteristics and 
TABLE 1. Distinguishing characteristics of Kluyveromyces group A species, ${ }^{a}$ including $K$. bacillisporus

\begin{tabular}{|c|c|c|c|c|c|c|c|c|}
\hline Characteristic & $K$ lodderae & $K$. yarrowii & K. phaffii & K. blattae & K. polysporus & $K$ africanus & K. bacillisporus & K. delphensis \\
\hline \multicolumn{9}{|l|}{ Carbon assimilation } \\
\hline Galactose & + & + & + & + & + & + & - & - \\
\hline Sucrose and raffinose & + & - & - & - & + & - & $\mathrm{s}$ or $\mathrm{w}$ & - \\
\hline Trehalose & + & - & - & - & + or $s$ & - & - & s or $w$ \\
\hline Ethanol & $\mathbf{s}$ & $\mathrm{w}$ or $\mathrm{s}$ & - or $\mathrm{s}$ & - & s or - & - & - & s \\
\hline Glycerol & + & v & + & - or w & + & - or $w$ & $\mathbf{s}$ & + \\
\hline Gluconic acid & - & - & $\mathbf{s}$ & - & + & - & + & $\mathbf{s}$ \\
\hline Lactic acid & + & - & - & - & - or $w$ & - & - & $\mathbf{w}$ \\
\hline Citric acid & - & - & - & - & + or $s$ & - & - & - \\
\hline 2-Ketogluconate & - & - & - & + & - & - & + & - \\
\hline Tannic acid & + & + & $\mathbf{w}$ & - & $\mathbf{w}$ & $\mathbf{w}$ & $\mathbf{s}$ & - \\
\hline $\begin{array}{l}\text { Nitrogen assimilation: } \\
\text { cadaverine }\end{array}$ & + or $s$ & - & - & - & - & - & - & - \\
\hline $\begin{array}{l}\text { Growth on glucose }(50 \%, \\
\text { wt/wt) }\end{array}$ & - & - & - & - & - & - & $\mathbf{s}$ & $\mathrm{s}$ or $\mathrm{w}$ \\
\hline $\begin{array}{l}\text { Growth in the presence of } \\
\text { cycloheximide }(100 \mu \mathrm{g} / \mathrm{ml})\end{array}$ & + & - & - & - & - & - & - & - \\
\hline Growth at $37^{\circ} \mathrm{C}$ & - & - & - & - & - or $w$ & - or $w$ & $\mathbf{w}$ & + \\
\hline Amino acid requirement & - & - & - & His & - & Met & - & - \\
\hline Ascospore shape & Ell or Ren & Sph & Ell or Ren & Sph or Ell & Ell or Ren & Ell or Ren & Bac & Ren \\
\hline Ascospore no. (maximum) & 4 & 4 & 4 & 9 & 100 & 16 & $4-8$ & 4 \\
\hline Sexual compatibility & Hom & Het & Hom & Hom & Hom & Hom & Hom & Hom \\
\hline $\mathrm{G}+\mathrm{C}$ content $(\mathrm{mol} \%)$ & 35.5 & 34.5 & 35.3 & 34.2 & 35.3 & 38.5 & 38.0 & 40.2 \\
\hline
\end{tabular}

${ }^{a}$ See reference 10. Abbreviations: w, weak; s, slow; His, histidine; Met, methionine; Ell, ellipsoidal; Ren, reniform; Sph, spherical; Bac, bacilliform; Hom, homothallic; Het, heterothallic.

nutritional profiles of these organisms were nearly identical, as described below.

Latin diagnosis of Kluyveromyces bacillisporus sp. nov. In medio liquido post dies 3 cellulae singulae, binae, aut in catenis brevis; cellulae ovoidae $(2-5 \times 4-7 \mu \mathrm{m})$. Post unum mensem sedimentum formatur. Cultura in agaro malti post dies $14\left(17^{\circ} \mathrm{C}\right)$, infimo-convexa, glabra, candida, et butyrosa.

In agaro farinae Zea mays post dies 14 nec mycelium nec pseudomycelium formatur. Post dies 3 in agaro malti (1\%), asci formantur, evanescentes post dies 5 . Ascosporae bacilliformes, quaternae interdum plures.

Glucosum fermentatur.

Sucrosum (exigue aut lente), glycerolum (lente), acidum gluconicum, glucono- $\Delta$-lactonum, 2-ketogluconatum, et acidum tannicum (lente) assimilantur at non inulinum, raffinosum, galactosum, melibiosum, lactosum, trehalosum, malto- sum, melezitosum, methyl- $\alpha$-D-glucosidum, amylum solubile, cellobiosum, salicinum, methyl- $\beta$-D-glucosidum, L-sorbosum, L-rhamnosum, D-xylosum, L-arabinosum, D-arabinosum, D-ribosum, methanolum, ethanolum, 1-propanolum, 2-propanolum, 1-butanolum, erythritolum, ribitolum, xylitolum, mannitolum, glucitolum, galactitolum, meso-inositolum, acidum lacticum, acidum succinicum, acidum citricum, acidum malicum, glucosaminum, $N$-acetylglucosaminum, acetonum, ethyl acetas, nec hexadecanum.

Natrium nitricum, natrium nitrosum, ethylaminum, lysinum, nec cadaverinum non assimilantur.

Ad crescentiam vitaminae externae necessariae sunt.

Augmentum in $36^{\circ} \mathrm{C}, 37^{\circ} \mathrm{C}$ (exigue).

$\mathrm{G}+\mathrm{C}$ acidi deoxyribonucleati $38.1 \mathrm{~mol} \%$ (stirps UWO(PS) 85-349.2 ${ }^{\mathrm{T}}$ ), $37.9 \mathrm{~mol} \%$ (stirps UWO(PS) 85-359.2).

Habitatio in Quercus emoryi in Arizona.

TABLE 2. DNA base compositions and DNA reassociation values (at $62^{\circ} \mathrm{C}$ ) for $K$. bacillisporus UWO(PS) $85-349.2^{\mathrm{T}}$ and members of selected other yeast species

\begin{tabular}{|c|c|c|c|c|c|}
\hline \multirow[b]{2}{*}{ Strain or prepn } & \multirow{2}{*}{$\underset{(\mathrm{mol} \%)^{a}}{\mathrm{G}+\mathrm{C} \text { content }}$} & \multicolumn{2}{|c|}{ Expt 1} & \multicolumn{2}{|c|}{ Expt 2} \\
\hline & & $\begin{array}{l}\% \text { Actual } \\
\text { binding }\end{array}$ & $\begin{array}{c}\% \text { Relative } \\
\text { binding }\end{array}$ & $\begin{array}{l}\% \text { Actual } \\
\text { binding }\end{array}$ & $\begin{array}{c}\text { \% Relative } \\
\text { binding }\end{array}$ \\
\hline Kluyveromyces bacillisporus UWO(PS) $85-349.2^{\mathrm{T} d}$ & $38.1 \pm 0.6$ & 76.6 & $(100)$ & 71.5 & $(100)$ \\
\hline Kluyveromyces bacillisporus UWO(PS) $85-359.2^{d}$ & $37.9 \pm 0.3$ & 76.6 & 100 & 72.3 & 101 \\
\hline Kluyveromyces drosophilarum UCD(FS\&T) $51-130^{\mathrm{T}}$ & $40.4 \pm 0.3$ & 0.0 & 0 & 2.3 & 3 \\
\hline Kluyveromyces aestuarii UCD(FS\&T) 77-72 & $39.7 \pm 0.2$ & 0.0 & 0 & 2.1 & 3 \\
\hline Kluyveromyces delphensis UCD (FS\&T) $56-2^{\mathrm{T}}$ & $40.3 \pm 0.3$ & 0.0 & 0 & 1.9 & 3 \\
\hline Kluyveromyces africanus $\mathrm{UCD}(\mathrm{FS} \& \mathrm{~T}) 57-16^{\mathrm{T}}$ & $38.2 \pm 0.5$ & 0.0 & 0 & 1.6 & 2 \\
\hline Pichia opuntiae UCD(FS\&T) $77-40^{\mathrm{T}}$ & $33.9 \pm 0.3$ & 0.0 & 0 & 1.0 & 1 \\
\hline Calf thymus & & 0.0 & 0 & -0.4 & 0 \\
\hline
\end{tabular}

${ }^{a}$ Average and standard deviation of at least five determinations.

${ }^{b}$ Corrected for $11.2 \%$ zero-time binding and $10.3 \%$ self-renaturation.

c Corrected for $1.9 \%$ zero-time binding and $3.7 \%$ self-ranaturation.

d Reassociation experiments were performed with purified nuclear DNA. 

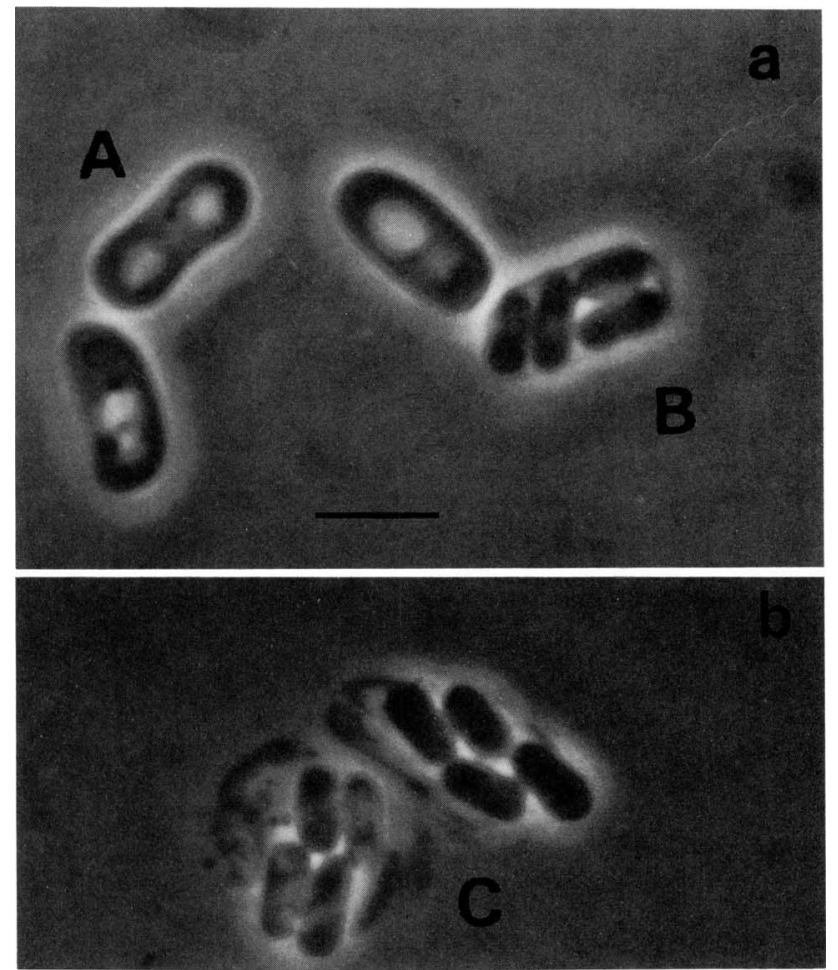

FIG. 1. Photomicrographs of $K$. bacillisporus UWO(PS) 85$349.2^{\mathrm{T}}$ on McClary's acetate agar: vegetative cells $(\mathrm{A})$ and ascus $(\mathrm{B})$ after 3 days and disrupted asci $(\mathrm{C})$ after 6 days at $25^{\circ} \mathrm{C}$. Bar $=5 \mu \mathrm{m}$.

Typus stirps UWO(PS) 85-349.2 ex Q. emoryi, in Arizona, isolata est. In collectione zymotica Centraalbureau voor Schimmelcultures, Delphi Batavorum, sub no. CBS 7720 deposita est.

Description of Kluyveromyces bacillisporus. Kluyveromyces bacillisporus (ba.cil.li.spor'us. L. nom. masc. adj. bacillisporus, with bacilliform spores, referring to the shape of the ascospores). In $0.5 \%$ yeast extract $-2 \%$ glucose broth after 3 days at $25^{\circ} \mathrm{C}$, the cells are ovoid or elongate (Fig. 1A), occur singly or in parent-bud pairs, and are 2 to 5 by 4 to $7 \mu \mathrm{m}$. A sediment is formed after 1 month.

On malt agar after 2 weeks at $17^{\circ} \mathrm{C}$, colonies are large, low convex, glabrous, smooth, white, and butyrous.
In Dalmau plate cultures on cornmeal agar after 2 weeks branching hyphae or pseudohyphae are not formed.

Ascospores are formed directly from diploid cells. Four cylindrical to bacilliform spores (Fig. 1) per ascus are formed after 3 days on McClary's acetate agar. Occasionally, some asci contain more than four ascospores (up to six to eight ascospores). Ascospores are also formed on other media, such as $1 \%$ malt extract agar or cornmeal agar. Evanescence (Fig. 1b) occurs after 5 days.

In fermentation tests a full tube of gas develops in about 2 to 3 days with glucose. Sucrose is not fermented.

The following carbon compounds are assimilated: sucrose (slowly and weakly), glycerol (weakly), gluconic acid, glucono- $\Delta$-lactone, 2-ketogluconic acid, and tannic acid (slowly). No growth occurs on inulin, raffinose, galactose, melibiose, trehalose, maltose, melezitose, lactose, methyl$\alpha$-D-glucoside, soluble starch, cellobiose, salicin, methyl- $\beta$ D-glucoside, L-sorbose, L-rhamnose, D-xylose, L-arabinose, D-arabinose, D-ribose, methanol, ethanol, 1-propanol, 2-propanol, 1-butanol, erythritol, ribitol, xylitol, mannitol, glucitol, galactitol, meso-inositol, lactic acid, succinic acid, citric acid, malic acid, glucosamine, $N$-acetylglucosamine, acetone, ethyl acetate, or hexadecane.

The following nitrogen compounds are not assimilated: sodium nitrate, sodium nitrite, ethylamine, lysine, and cadaverine.

The diazonium Blue $B$ reaction is negative.

No growth occurs in vitamin-free medium.

Growth in amino acid-free medium is positive.

Growth occurs at $36^{\circ} \mathrm{C}$; growth at $37^{\circ} \mathrm{C}$ is weak.

Gelatin liquefaction is negative.

Casein hydrolysis occurs but is slow.

Acid is not formed on chalk agar.

Urease activity is negative.

Lipolytic activity on Tween 80 agar is negative.

Amyloid compounds are not produced.

Growth on $50 \%$ glucose-yeast extract agar occurs but is slow.

Growth occurs on YM agar containing $10 \% \mathrm{NaCl}$; growth on $\mathrm{YM}$ agar containing $12.5 \% \mathrm{NaCl}$ is weak; and growth does not occur on $\mathrm{YM}$ agar containing $15 \% \mathrm{NaCl}$.

Growth in the presence of $10 \mu \mathrm{g}$ of cycloheximide per $\mathrm{ml}$ is weak; no growth occurs in the presence of $100 \mu \mathrm{g}$ of cycloheximide per $\mathrm{ml}$.

No growth occurs in the presence of $8 \mu \mathrm{g}$ of digitonin per $\mathrm{ml}$ at $25^{\circ} \mathrm{C}$.

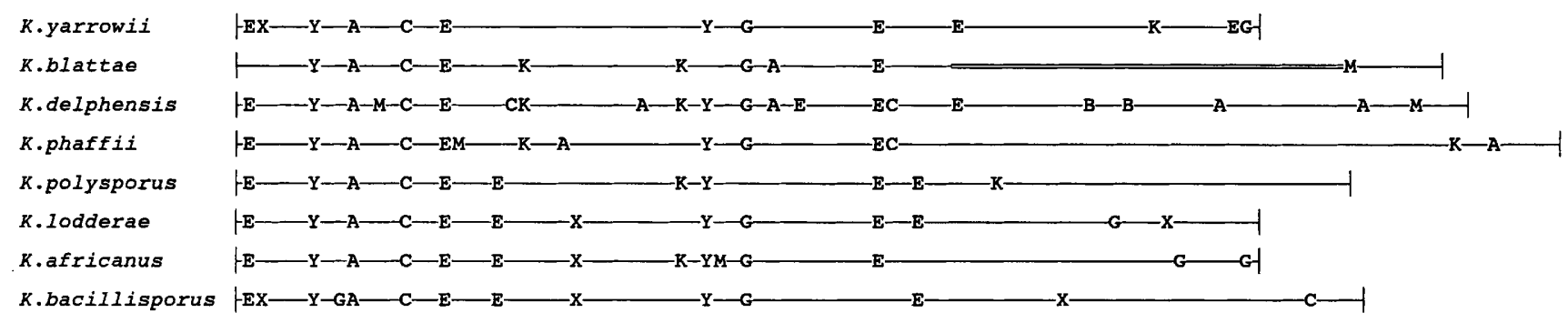

SSU LSU IGS

FIG. 2. Restriction maps of the ribosomal DNAs of Kluyveromyces group A species. Data from reference 5 and this study. The approximate positions of the small-subunit (SSU), 5.8S (5.8), and large-subunit (LSU) coding regions and of the intergenic spacer (IGS) are shown. Restriction site abbreviations: A, ApaI; B, BamHI; C, SacI; E, EcoRI; G, BglII; K, KpnI; M, SmaI; X, XhoI; Y, XbaI. 


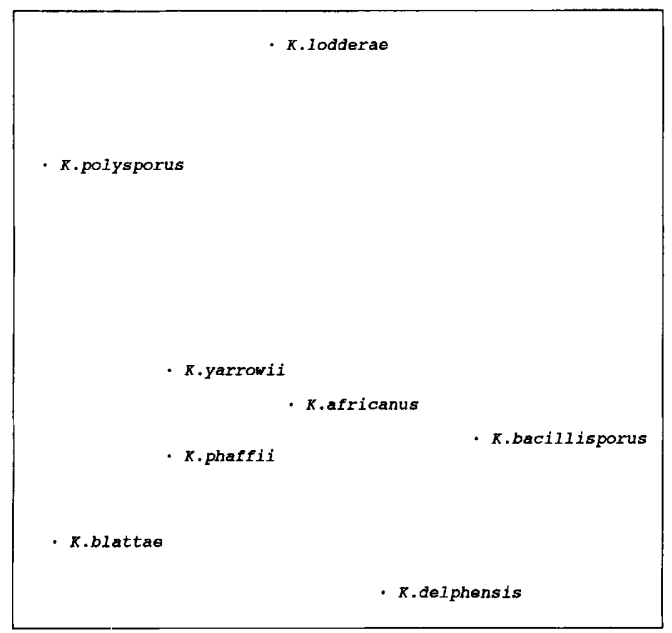

FIG. 3. Ordination of Klyuveromyces group A species by nonmetric multidimensional scaling of the Euclidean distance matrix of the discriminatory characteristics shown in Table 1 . The axes are dimensionless.

The $\mathrm{G}+\mathrm{C}$ contents of the nuclear DNAs of strains UWO(PS) $85-349.2^{\mathrm{T}}$ and UWO(PS) 85-359.2 are 38.1 and $37.9 \mathrm{~mol} \%$, respectively.

The habitat is exudates of Emory oak ( $Q$. emoryi) in Arizona. The type strain of Kluyveromyces bacillisporus, strain UWO(PS) 85-349.2, was isolated from an Emory oak exudate in Happy Valley, near Tucson, Ariz. This strain has been deposited in the collection of the Yeast Division of the Centraalbureau voor Schimmelcultures, Delft, The Netherlands, as strain CBS 7720, and in the American Type Culture Collection, Rockville, Md., as strain ATCC 90019.

DNA studies. Because $K$. bacillisporus exhibited certain similarities in morphology, physiology, and DNA base composition to Kluyveromyces africanus and Kluyveromyces delphensis, DNA reassociation experiments involving these organisms and other yeast strains were performed (Table 2). Our results support the view that $K$. bacillisporus represents a separate species. The restriction maps of the ribosomal DNAs of $K$. bacillisporus and the type strains of other

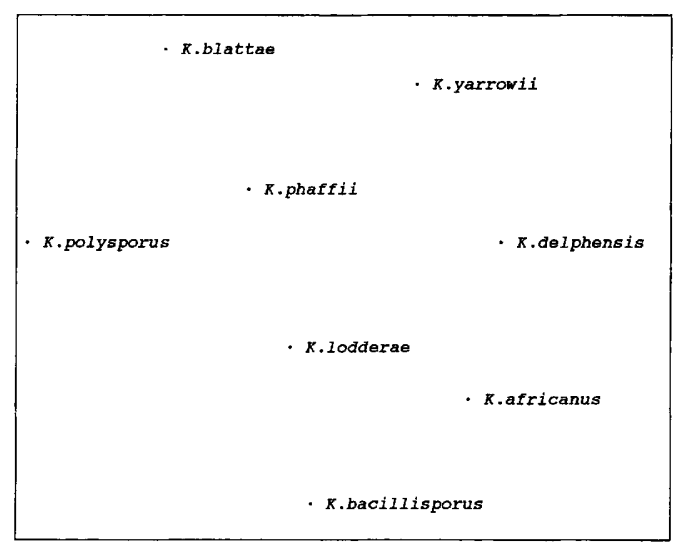

FIG. 4. Ordination of Kluyveromyces group A species by nonmetric multidimensional scaling of the mismatch matrix of the ribosomal DNA restriction maps shown in Fig. 2. The axes are dimensionless.
Kluyveromyces species (Fig. 2) also support the view that $K$. bacillisporus deserves species status.

\section{DISCUSSION}

We consider it preferable not to base the description of a new species on three strains isolated from a single locality. In this case, however, we feel justified in doing this because extensively sampled plants and associated soils or insects in Arizona and other semiarid areas have failed to yield any similar yeasts. Such rarity is not uncommon among the Kluyveromyces species listed in Table 1, all of which were defined on the basis of few isolates (usually a single strain). These organisms have been reisolated only infrequently, and yet they have withstood extensive taxonomic scrutiny.

$K$. bacillisporus is typical of group A Kluyveromyces species as defined by Poncet (10). In addition to the responses shown in Table 1, group A species assimilate few carbon compounds and never utilize both ethylamine and lysine as nitrogen sources, unlike other members of the genus. Among the species in group A, $K$. bacillisporus shares with $K$. delphensis a moderate osmotolerance and an inability to utilize galactose; it shares with Kluyveromyces blattae the ability to utilize 2-ketogluconate. The overall phenetic position of $K$. bacillisporus is shown in Fig. 3, which is based on the multivariate distances calculated from the data in Table 1 . Thus, in terms of overall similarity, $K$. bacillisporus appears to be most similar to $K$. africanus and $K$. delphensis and most dissimilar to Kluyveromyces lodderae and Kluyveromyces polysporus. A phenetic analysis of ribosomal DNA restriction maps (Fig. 4) confirms the proximity of $K$. bacillisporus to $K$. africanus, but also shows that many restriction sites are shared with $K$. lodderae. The general pattern further substantiates the view that all previously described group A Kluyveromyces species are distinct, because no obvious similarity clusters can be identified. A more reliable estimate of the correct phylogenetic position of $K$. bacillisporus in the genus Kluyveromyces will no doubt emerge from the eventual analysis of suitable rRNA sequences.

\section{ACKNOWLEDGMENTS}

This work was supported by grants from the Natural Science and Engineering Research Council of Canada to M.-A.L., and by grants DEB 81-08679 and DEB 81-08898 from the National Science Foundation to W.T.S. and H.J.P., respectively.

We are indebted to James S. Haudenshield for his expert technical assistance with the DNA base composition determinations and DNA reassociation experiments. We gratefully acknowledge the cooperation of Phil Ganter with the collection efforts that resulted in the isolation of the new yeast species.

\section{REFERENCES}

1. Bowles, J. M., and M. A. Lachance. 1983. Patterns of variation in the yeast florae of exudates in an oak community. Can. J. Bot. 61:2984-2995.

2. Ganter, P. F., W. T. Starmer, M. A. Lachance, and H. J. Phaff. 1986. Yeast communities from host plants and associated Drosophila in southern Arizona: new isolations and analysis of the relative importance of hosts and vectors on community composition. Oecologia 70:386-392.

3. Holzshu, D. L., H. L. Presley, M. Miranda, and H. J. Phaff. 1979. Identification of Candida lusitaniae as an opportunistic yeast in humans. J. Clin. Microbiol. 10:202-205.

4. Kruskal, J. B. 1964. Nonmetric multidimensional scaling: a numerical method. Psychometrika 29:115-129.

5. Lachance, M. A. 1988 . Restriction mapping of rDNA and taxonomy of Kluyveromyces van der Walt emend. van der Walt. 
Yeast 5(Special Issue):S379-S383.

6. Lachance, M. A. 1990. Ribosomal DNA spacer variation in the cactophilic yeast Clavispora opuntiae. Mol. Biol. Evol. 7:178193.

6a.Lachance, M. A. Unpublished data.

7. Lachance, M. A., B. J. Metcalf, and W. T. Starmer. 1982. Yeasts from exudates of Quercus, Ulmus, Populus, and Pseudotsuga: new isolations and elucidation of some factors affecting ecological specificity. Microb. Ecol. 8:191-198.

8. Lachance, M. A., W. T. Starmer, and H. J. Phaff. 1990. Metschnikowia hawaiiensis sp. nov., a heterothallic haploid yeast from Hawaiian morning glory and associated Drosophila. Int. J. Syst. Bacteriol. 40:415-420.

9. Phaff, H. J., and E. P. Knapp. 1956. The taxonomy of yeasts found in exudates of certain trees and natural breeding sites of some Drosophila. Antonie van Leeuwenhoek 22:117-130.

10. Poncet, S. 1973. Taxonomie numérique du genre Kluyveromyces. Mycopathol. Mycol. Appl. 51:267-281.

11. Price, C. W., G. B. Fuson, and H. J. Phaff. 1978. Genome comparison in yeast systematics: delimitation of species within the genera Schwanniomyces, Saccharomyces, Debaryomyces, and Pichia . Microbiol. Rev. 42:161-193.

12. van der Walt, J. P., and D. Yarrow. 1984. Methods for the isolation, maintenance, classification, and identification of yeasts, p. 45-104. In N. J. W. Kreger-van Rij (ed.), The yeasts, a taxonomic study, 3rd ed. Elsevier Science Publishers B. V., Amsterdam. 